The Effectiveness of Transgovernmental Networks

Managing the Practical Application of European Integration in the case of Solvit.

Martinsen, Dorte Sindbjerg; Hobolth, Mogens

Published in:

New directions in the Effective Enforcement of EU Law and Policy

Publication date:

2016

Citation for published version (APA)

Martinsen, D. S., \& Hobolth, M. (2016). The Effectiveness of Transgovernmental Networks: Managing the

Practical Application of European Integration in the case of Solvit. In S. Drake, \& M. Smith (Eds.), New directions in the Effective Enforcement of EU Law and Policy (pp. 152-175). Edward Elgar Publishing. 


\title{
The Effectiveness of Transgovernmental Networks: Managing the Practical Application of European Integration in the case of Solvit.
}

\author{
Dorte Sindbjerg Martinsen ${ }^{1}$ and Mogens Hobolth ${ }^{2}$
}

Published in Sara Drake and Melanie Smith (2016) "New Directions in the Effective Enforcement of EU Law and Policy”, Edward Elgar Publishing, pp. 152-175

http://www.e-elgar.com/shop/new-directions-in-the-effective-enforcement-of-eu-law-and-policy

\begin{abstract}
The practical realization of European Union (EU) rights and obligations depends to a considerable extent on how national public authorities apply EU legislation in their daily work. A growing number of EU compliance studies have probed the transposition of EU law and discussed the importance and shortcomings of the European Commission, the Court of Justice of the European Union (CJEU) and national courts as central and decentralised enforcers. However, the practical application of EU rights and obligations remains rather unexplored. Drawing on survey data covering EU-27 and three EEA states participating in Solvit, an internal market problem-solving

\footnotetext{
${ }^{1}$ Corresponding author. Professor at Department of Political Science, University of Copenhagen. E-mail: dm@ifs.ku.dk. ORCID 0000-0002-2113-0950.

${ }^{2}$ Mogens Hobolth holds a Ph.D. from London School of Economics. He currently works at the Danish Immigration Service and as external lecturer at the Department of Political Science, University of Copenhagen. ORCID 0000-00030696-7645.
} 
network, this paper investigates the role of transgovernmental networks in enforcing and managing the daily application of EU legislation by national authorities. We show that informal conflict resolution has become an important and effective tool for addressing misapplication of EU law. Anchored in national public administrations yet working under the 'shadow of hierarchy' (namely the Commission) transgovermental networks are in fact able to improve the compliance of domestic authorities.

\section{Introduction}

This chapter aims to add to the discussion of new governance mechanisms to address and solve problems of misapplication of EU law. It draws on theory on transgovernmental networks from international relations studies and applies these to examine the practical application of, and compliance with, EU law.

Compliance with international agreements continues to be a challenge to international politics, and has increasingly received scholarly attention, not least within European Union studies. The 'governance dilemma' of a globalised world is still pertinent and international organizations continue to lack suitable instruments to monitor and oversee that states fulfil their international obligations. ${ }^{3}$ If the agreements of international organizations are not complied with they are of little value. Therefore to inquire into states' compliance with the international agreements they have ratified, is to inquire into the reach, regulatory strength and de facto impact of that international organization. The European Union is a prominent example of how important compliance is to the legitimacy and cohesiveness of an international organization. How to improve compliance and the

\footnotetext{
${ }^{3}$ B. Eberlein and A.L. Newman, 'Escaping the Intergovernmental Governance Dilemma? Incorporated Transgovrnmental Networks in the European Union' (2008) Governance 25.
} 
practical application of EU rules is generally high on the European agenda. Scholarly research on international and regional integration within political science and law has advanced our knowledge considerably during the last decades. A growing number of studies have examined the extent to which EU Member States transpose binding decisions into national law on time and correctly as well as what may explain variation in transposition between the Member States. ${ }^{4}$ However we still know relatively little about compliance beyond the transposition of EU law. ${ }^{5}$ For example, which instruments improve application of EU rules in practice? What compliance problems arise after transposition of EU law has taken place, i.e. once an EU regulation applies in practice, and how common are these problems? Have new modes of governance developed to handle misapplication on the ground?

The EU constitutes the most legalized international organization in the world, able to judicially address and sanction non-compliance, and is exceedingly effective in doing so compared to other international organizations. ${ }^{6}$ However although the importance of management tools to

\footnotetext{
${ }^{4}$ See for example T.A. Börzel, T. Hofmann, D. Panke and C. Sprungk 'Obstinate and inefficient: Why Member States do not comply with European law' (2010) 43(11) Comparative Political Studies 1363; M. Haverland and M. Romeijin 'Do Member States make European policies work? Analysing the EU transposition deficit' (2007) 85(3) Public Administration 757; M. Haverland, B. Steuenberg and F. van Waarden 'Sectors at different speeds: Analysing transpostion deficits in the European Union' (2011) 49(2) Journal of Common Market Studies 265; B. Steuenberg and D. Toshkov 'Comparing transposition in the 27 Member States of the EU: the impact of discretion and legal fit' (2009) 16(7) Journal of European Public Policy 951; T. König and B. Luetgert 'Troubles with Transposition? Explaining Trends in Member-State Notification and the Delayed Transposition of EU Directives' (2009) British Journal of Political Studies 163.

${ }^{5}$ E. Versluis 'Even rules, uneven practices: Opening the 'black box' of EU law in action' (2007) 30(1) West European Politics 50.

${ }^{6}$ J. Tallberg 'Paths to compliance: Enforcement, management and the European Union' (2002) 56(3) International Organization 609.
} 
improve compliance has been emphasized in international relations and European studies, ${ }^{7}$ scholarly work tends to focus on central and decentralised enforcement mechanisms, i.e. the infringement procedures monitored by the European Commission and private litigants and national courts bringing preliminary references to the European Court of Justice and. ${ }^{8}$ We know relatively little about concrete management instruments, how they work, how they have developed and whether they are effective means to improve compliance.

This paper examines the role of transgovernmental networks (TGNs) in monitoring and overseeing the practical application of EU law, focusing on the SOLVIT network.

Transgovernmental networks differ from transnational networks by having government representatives as the actors instead of independent experts or representatives from interest organisations which are main actors transnational networks. ${ }^{9}$ The chapter enquires into the modus operandi of TGNs and the effectiveness of this new governance tool as mode of enforcing EU law. It finds that TGNs have developed as important and effective monitoring instruments for the practical application of EU law, operating mainly in line with management logics. We define effective enforcement as the problem-solving capacity and resolution speed of the network in question. Problem-solving capacity concerns the ability of the network to identify, mediate and solve problems of misapplied EU law. Resolution speed concerns the time used to solve such problems. These dual elements of effective enforcement thus defines effectiveness both in terms of

\footnotetext{
${ }^{7}$ A.Chayes and A.H. Chayes 'On compliance' (1993) 47(2) International Organization 175; Tallberg (n 6); König and Luetgert (n 4) 167.

${ }^{8}$ K.J. Alter and J. Vargas 'Explaining Variation in the Use of European Litigation Strategies. European Community Law and British Gender Equality Policy' (2000) Comparative Political Studies 452; K. Alter 'Establishing the supremacy of European Law: The making of an international rule of law in Europe' (Oxford University Press 2001); Tallberg (n 6).

${ }^{9}$ For an analysis of transnational networks see [Versluis chapter [4 ]]
} 
the instrumental ability to enforce EU law as well as the timely aspect of it. The latter part of the definition is often disregarded, but is highly important if EU law is to work on the ground, for citizens and enterprises.

\section{Effectuating European Integration: the state of art in political science studies}

By virtue of extensive EU transposition and compliance studies, political scientists have developed a fairly good grasp of whether EU directives are transposed on time, but we have little scholarly insight into 'the EU law in action', i.e. the practical application of EU rules. ${ }^{10}$ Furthermore, our knowledge remains limited in relation to how national public administrations respond to and assume the obligations which make EU law work at all levels of society. Does the application of EU law function in practice when domestic authorities at the national, regional and local levels are to administer in accordance with supranational rules?

Compared to other international organisations, the EU is seen to have developed fairly efficient enforcement procedures through which non-compliance is detected and pursued ${ }^{11}$. As a result, non-compliance is seen by some to be a temporal phenomenon. ${ }^{12}$ Concerning the supranational enforcement practices, the vital role played by the European Commission and the Court of Justice of the European Union (CJEU) towards ensuring state compliance stand clear. ${ }^{13}$ The role played by interest groups and national courts has also been emphasised as a key

\footnotetext{
${ }^{10}$ E. Versluis 'Even rules, uneven practices: Opening the 'black box' of EU law in action' (2007) 30(1) West European Politics 50.

${ }^{11}$ However, see Chapters 1 and 2 of this collection for a less positive view.

12 Tallberg (n 6) 614.

${ }^{13}$ Tallberg (n 6); J. Tallberg ‘European governance and supranational institutions: Making states comply’ (Routledge 2003)
} 
decentralised means pushing for national compliance. ${ }^{14}$ Tallberg has argued that this unique combination of central and decentralised enforcement mechanisms makes the EU very 'effective in combating detected violations'. ${ }^{15}$

However, the extent to which this model of 'dual enforcement' is able to detect and resolve the full scope of EU law violation is still open to critical examination. Central enforcement mechanisms have their shortcomings. The Commission lacks the resources and capacity to uncover and legally pursue the whole EU-wide spectre of non-compliance. ${ }^{16}$ Furthermore, the decentralized strategies whereby non-compliance is challenged in national courts are no 'panacea' for the enforcement of EU law, as individuals acting as litigants often lack the necessary resources and time to carry out legal proceedings. ${ }^{17}$ Finally, the EU is 'currently in a state of turmoil' ${ }^{18}$ where both economic and legitimacy crises are likely to affect Member States' willingness and ability to comply with EU decisions. ${ }^{19}$ The ability to enforce its rules and regulation is closely linked to the EU's credibility as a political system and as a system founded on the rule of law. According to

${ }^{14}$ Alter and Vargas (n 8); Alter (n 8); L.J. Conant 'Justice contained: Law and politics in the European Union' (Cornell University Press 2002); Tallberg (n 6); Tallberg (n 13); M. Wind, D.S. Martinsen and G.P. Rotger 'The Uneven Legal Push for Europe. Questioning Variation when National Courts go to Europe' (2009) European Union Politics 63; R. Slepcevic 'The judicial enforcement of EU law through national courts: possibilities and limits' (2009) 16(3) Journal of European Public Policy 378.

${ }^{15}$ Tallberg (n 6) 610.

${ }^{16}$ Börzel, Hofmann, Panke and Sprungk (n 4) 1374; G. Falkner and M. Hartlapp 'Problems of operationalization and data in EU compliance research' (2009) 10(2) European Union Politics 281, and see Chapter 2 of this volume.

${ }^{17}$ See Chapter 1 of this volume and Slepcevic (n 14) 391.

${ }^{18}$ G. Falkner 'The JCMS Annual Review Lecture. Is the European Union Losing Its Credibility?' (2013) 51 Journal of Common Market Studies 13.

${ }^{19}$ Although as Commission's statistics on centralized enforcement do not seem to betray any worsening compliance picture so far. 
Falkner, the EU is currently in need of restoring societal confidence that its commitments are 'real and binding' ${ }^{20}$

\subsection{The practical application of EU law}

We still know remarkably little about the practical application of EU rules, that is, how the rules work in practice and are applied 'out there' in order to regulate the daily lives and doings of citizens and enterprises. With some exceptions, ${ }^{21}$ most studies dealing with implementation have examined the formal stage of transposition, also termed legal or judicial implementation, in which a directive is transposed into national legislation. ${ }^{22}$ In these analyses, infringement proceedings and transposition records generally constitute the focus of research upon which conclusions are made on whether Member States are EU compliers. ${ }^{23}$ However, the same scholars point out that infringements may not offer a representative sample of all of the violations of supranational

\footnotetext{
${ }^{20}$ Falkner (n 18) 14.

${ }^{21}$ Versluis (n 10); G. Falkner, M. Hartlapp and O. Treib 'Worlds of compliance: Why leading approaches to European Union implementation are only 'sometimes-true theories' (2007) 46(3) European Journal of Political Research 395; Slepcevic (n 14).

${ }^{22}$ See for example T.A. Börzel 'Non-compliance in the European Union: Pathology or statistical artefact?' (2001) 8(5) Journal of European Public Policy 803; Börzel, Hofmann, Panke and Sprungk (n 4); P. Bursens 'Why Denmark and Belgium have different implementation records: On transposition laggards and leaders in the EU' (2002) 25(2) Scandinavian Political Studies 173; E. Mastenbroek 'Surviving the deadline: The transposition of EU directives in the Netherlands' (2003) 4(4) European Union Politics 371; Haverland and Romeijn (n 4); Steuenberg and Toshkov (n 4); for overviews, see E. Mastenbroek ‘EU compliance: Still a ‘black hole’?’ (2005) 12(6) Journal of European Public Policy 1103; O. Treib 'Implementing and complying with EU governance outputs' (2008) 3(5) Living Reviews in European Governance.

${ }^{23}$ See Falkner and Hartlapp (n 16) for a critical discussion of the data sources used.
} 
obligations, but rather only the 'tip of the non-compliance iceberg'. ${ }^{24} \mathrm{We}$ are thus left to assume that there are many other incidents of misapplication beyond formal transposition than those detected and pursued by means of infringement proceedings.

Whereas judicial implementation is a process steered mainly by member state governments and the core executive, correct practical application depends on the extent to which national public authorities at different levels of governance understand and act in accordance with the EU rule of law. Correct practical implementation also depends on the extent to which the correctness of implementation is controlled. As noted by Falkner, there is no reason to think that EU law is generally obeyed. An effective law enforcement regime depends on 'basic pillars to work adequately: public administrations, labour inspectorates, court systems, media and civil society institutions that could act as whistleblowers and intermediate potential problems. ${ }^{25}$

In order to address problems arising in the practical application of EU law, the EU has supplemented its coercive instruments of enforcement with cooperative means of management. ${ }^{26}$ Side by side with the deterrent message of enforcement by sanctions, Member States are monitored by means of a more informal, softer managerial approach. This management approach implies dialogue and mutual trust. ${ }^{27}$ The management approach recognises that sometimes non-compliance is not the mere result of deliberate behaviour, that is, the member state neglecting or ignoring to fulfil its EU obligations in a calculated manner. Instead, non-compliance can be caused by

\footnotetext{
${ }^{24}$ Börzel, Hofmann, Panke and Sprungk (n 4) 1374.

${ }^{25}$ Falkner (n 18) 22.

${ }^{26}$ Tallberg (n 6); Tallberg (n 13); Börzel, Hofmann, Panke and Sprungk (n 4); M. Hartlapp 'On enforcement, management and persuasion: Different logics of implementation policy in the EU and the ILO' (2007) 45(3) Journal of Common Market Studies 653.

${ }^{27}$ See also Ch 2 of this volume.
} 
ambiguous treaty language, complex secondary legislation, as well as a lack of administrative capacity and/or transparency. Different solutions are therefore required:

'...the improvement of dispute resolution procedures goes to the problem of ambiguity; technical and financial assistance may help cure the capacity deficit; and transparency will make it likelier that, over time, national policy decisions are brought increasingly into line with agreed international standards'. ${ }^{28}$

The management view introduces an important shift in the EU theoretical and empirical approach to compliance. It departs from a 'command and control' understanding of which instruments best solve problems of the misapplication of law. In order to improve compliance, the non-complier should be assisted to solve the problems - instead of sued and sanctioned. Dispute settlements by means of management are based on dialogue, trust, involvement, capacity building and transparency. ${ }^{29}$ Problem solving involves mediation of positions between all the involved parties so that they come to terms with the mutual solution identified. In this way, the process of problem solving aims to find a solution that appeases and works for all the involved parties. The dispute solving mechanisms differ from legal proceedings in court where the court concludes on the 'correct' legal interpretation, which may ultimately please neither parties. Transgovernmental networks constitute such forums for problem-solving, beyond traditional central and decentralized enforcement mechanisms.

\footnotetext{
${ }^{28}$ Chayes and Chayes (n 7).

${ }^{29} \mathrm{Ch} 4$ discusses these virtues in relation to transnational agencies as well, and in $\mathrm{Ch} 3$ this would be considered a type of responsive regulation..
} 


\section{Transgovernmental networks as new means of executive governance}

Political scientists recognize that transgovernmental networks have emerged as a constitutive part of European integration. ${ }^{30}$ Whilst the importance of transgovernmental cooperation has long been accepted within the study of international relations, the scope and the policy areas covered by TGNs with the EU's infrastructure are currently found to have taken on "completely new dimensions". 31 A transgovernmental network consists of regular and purposive relations between government actors, dealing with cross-border policies and problems. The government actors represent the state but operate at levels below the heads of states. They act as sector-specific experts who together develop shared, standard operating practices, by means of regular and purposive action, focusing on sector specific problems such as environmental sustainability, human rights, data protection, electricity, justice and home affairs. ${ }^{32}$ Civil servants or 'regulators' are key actors in such networks, serving as the new diplomats of global governance. ${ }^{33}$ When they interact with their foreign peers, they bring with them their domestic expertise and views, but are forced to exchange these views and present solutions on collective problems arising from transgovernmentalism in practice.

TGNs serve as fora of sharing information, building capacity, developing experience and learning between the actors involved and thus rely on management, rather than enforcement,

\footnotetext{
${ }^{30}$ P.W. Thurner and M. Binder 'European Union transgovernmental networks: The emergence of a new political space beyond the nation-state?' (2009) 48(1) European Journal of Political Research 80; M. Hobolth and D.S. Martinsen 'Transgovernmental Networks in the European Union: Improving Compliance Effectively?' (2013) 20(10) Journal of European Public Policy 1406.

${ }^{31}$ Thurner and Binder (n 30) 83.

${ }^{32}$ A. Slaughter 'A New World Order' (Princeton University Press 2004); Thurner and Binder (n 30); Eberlein and Newmann (n 3).

${ }^{33}$ Slaughter (n 32) 63.
} 
logics in the way they monitor disputes. ${ }^{34}$ One of the concrete impacts that TGNs can have is to improve compliance with international rules. ${ }^{35}$ Such transgovernmental enforcement networks are found to play a crucial role in the effectuation of international rules as they lower the transaction costs of enforcement. Although TGNs are accepted as an important and expanding form of governance, able to provide a fast and flexible alternative to the formal procedures of international organisations, ${ }^{36}$ we know little about their actual modus operandi, less about their effect and what may condition effectiveness. Their effectiveness is often claimed, but not tested or systematically explored. ${ }^{37}$ Can informal problem-solving mechanisms effectively monitor and oversee compliance problems of supranational governance? Can they monitor the practical application of EU law, and if so, do all units in a network function equally effectively? What may explain variations in effectiveness across the network? These questions will be examined below.

\section{The study of the Solvit network: Data, method and scope}

The transgovernmental network of SOLVIT is examined in this chapter. The Solvit network monitors the practical application of internal market law within the EU Member States as well as the three Member States of the European Economic Area (EEA); Norway, Lichtenstein and Iceland. Solvit was established in $2001^{38}$ and handles complaints from citizens and businesses concerning the application of European law in cross-border cases. Conflicts are resolved via a dialogue between

\footnotetext{
${ }^{34}$ A. Slaughter and T.N. Hale 'Transgovernmental networks and multi-level governance' in H. Enderlein, S. Wälti and M. Zürn (eds.), 'Handbook on Multi-level Governance’ (Cheltenham \& Northampton 2010) 347.

${ }^{35}$ Slaughter (n 32) 44.

${ }^{36}$ Eberlein and Newmann (n 3) 27.

${ }^{37}$ Eberlein and Newmann (n 3) 35.

${ }^{38}$ European Commission 'Recommendation on Principles for Using "Solvit": The Internal Market Problem Solving Network' COM (2001) 893.
} 
national Solvit centres, domestic authorities complained about and in some instances also the Commission. The network today processes a notable amount of cases and claim a high success rate in resolving disputes. ${ }^{39}$ Although examining the single case of the internal market, Solvit mirrors a more general tendency in the European Union where regulatory networks are established to carry out key functions of executive governance. ${ }^{40}$ Furthermore, the problems arising in practice when internal market law is to be applied essentially mirrors the challenges confronting national authorities, businesses and citizens when practising the rules of global governance.

In order to examine the work-mode and effectiveness of a transgovernmental network, we conducted an online survey enquiring into the characteristics and modes of the Solvit network. The survey was sent to all 30 national Solvit centres, i.e. EU-27 as well as Iceland, Norway and Liechtenstein as part of the European Economic Area (EEA). ${ }^{41}$ The survey was carried out in the first half of 2011. It was presented as solely academic in its purpose. Most of the centres responded to our first enquiry. The centres that did not fill out the survey were subsequently contacted by email and telephone. Over time, all of the centres answered and we thus managed to obtain a full

\footnotetext{
${ }^{39}$ European Commission 'Background: Annual reports' <http://ec.europa.eu/solvit/site/background/index_en.htm> accessed 3 September 2011, European Commission '28th Annual report on monitoring the application of EU Law' COM (2011) 588.

${ }^{40}$ TRESS (social security) and IMPEL (environment) regulatory networks are similar to this type of network in the way they also monitor and report on misapplication of European legislation (See www.tress-network.org and impel.eu). Also Eberlein and Newmann (n 3); point to the increasing role of TGNs across policy areas in monitoring and overseeing the compliance with EU law.

${ }^{41}$ M.P. Couper 'Web surveys: A review of issues and approaches' (2000) 64 Public Opinion Quarterly 464; M.P. Couper, M.W Traugott, and M.J. Lamias ‘Web survey design and administration' (2001) 65 Public Opinion Quarterly 230; D.A. de Vaus 'Surveys in social research' (5th edn, Routledge 2001); for a critical discussion, see R.D. Fricker and M. Schonlau 'Advantages and disadvantages of Internet research surveys: Evidence from the literature' (2002) 14(4) Field Methods 347.
} 
response rate. In addition, data was provided to us by the European Commission in summer 2012 on the resolution rates of the individual Solvit centres, extracted from the Commission's database. This data is not publicly available but was provided by the Commission on our request on the basis of previously established contact.

The survey themes and questions were put together following close studies of the publicly available documents on Solvit together with explorative interviews with the national centres in the United Kingdom and Denmark. The explorative interviews were used to test our initial theoretical ideas and ensure that the questions would address the key dynamics of the network and appear understandable within its context. ${ }^{42}$ The British and Danish Solvit centres also agreed to read through a draft of the survey and provided a final set of comments on our draft. Finally, we engaged in informal dialogue with the Commission on our project and questionnaire. We used this approach to ensure as fully as possible that the questions would be intelligible to the network participants. Towards the end of the survey, we also asked the participants if we might return with follow-up questions.

The survey consisted of 30 questions. The centres could mainly respond to them on a scale such as increased/decreased or strongly agree/strongly disagree. We thereby attempted to obtain answers that would be more easily summarised across all participating states. The key questions also included a text box for additional comments.

Our enquiry addressed three overall themes. The first was the resources and relations of the network. Here, we explored the amount of contact with other centres, other parts of the national public administration, the Commission and changes in the level of institutionalisation over time. The second was the case management process in practice. This section explored the efficiency of the network, the role and monitoring of the Commission and reasons for

\footnotetext{
${ }^{42}$ Couper (n 41) 475f.
} 
misapplication. The third and final section examined the values of the network. Here, we asked questions concerning the network's source of legitimacy, the character of an ideal case solution and their orientation towards either national or European interests. The specific survey questions asked are stated alongside each illustration reporting on our findings. Apart from the survey data and explorative interviews, the analysis draws on relevant supplementary material, such as the Commission's annual reports on the network.

\subsection{Informal dispute settlements in the EU: Presenting the Solvit network}

The European Commission officially proposed the establishment of the Solvit network in late 2001, enabling citizens or enterprises to submit complaints to nationally based centres concerning the misapplication of internal market rules. ${ }^{43}$ The Council of Ministers endorsed the Commission's proposal shortly afterwards, and the network started handling cases in $2002 .^{44 ;}$ The executive summary of the Commission's initial communication highlighted the purposes and means of the network. It was to provide effective problem-solving in relation to cross border disputes in the sphere of the internal market by means of administrative dispute settlements, enhanced transparency and peer-pressure. Specifically, the envisioned network was to be based on an online database where examined disputes could be registered and solutions reported on. Furthermore, it was to undertake preventive actions by seeking to remove the causes of recurring problems as well as to promote itself and target information to citizens and business. ${ }^{45}$ The Commission proposed an

\footnotetext{
${ }^{43}$ European Commission, 'Communication from the Commission to the Council, the European Parliament, the Economic and Social Committee and the Committee of the Regions - Effective problem solving in the Internal Market ("SOLVIT")' COM (2001) 702.

${ }^{44}$ Council of the European Union, 'Internal market problem-solving - Council conclusions on the "SOLVIT" network' 6503/02 (Presse 41 - G), European Commission (n 39)

${ }^{45} \mathrm{COM}(2001) 702$
} 
alternative dispute settlement mechanism intended to offer speedier problem-solving than the formal setting of cases before the CJEU could offer. When the internal market does not appear to function in practice:

... speedy redress needs to be available. Resolving such practical problems is critical to the credibility of the Internal Market in the eyes of citizens and economic operators, particularly small and medium-sized businesses. We know from experience, however, that resolving problems can take a long time $[\ldots]$ This prevents a lot of people from doing what they are entitled to by Community law. When this happens, confidence in the European Union is eroded. $^{46}$

These original aims and means still represent today the core idea of Solvit as a network. As a network, Solvit appeals directly to EU citizens and businesses, offering them fast, practical solutions to disputes over the application of internal market rules. ${ }^{47}$ All 27 Member States and Norway, Lichtenstein and Iceland have established a Solvit centre, based within the national central administration, in most cases within the ministry of economic or foreign affairs. ${ }^{48}$

The dispute settlement work-mode is quite unique. It is based on recurrent dialogues between citizens, companies, Solvit centres and the responsible national authorities. A complaint is first

\footnotetext{
${ }^{46}$ Ibid: 3

${ }^{47}$ European Commission, 'SOLVIT 2010 report: Development and performance of the SOLVIT network' <http://ec.europa.eu/solvit/site/docs/solvit_2010_report_en.pdf> accessed 3 September 2011, European Commission, 'About SOLVIT'<http://ec.europa.eu/solvit/site/about/index_en.htm> accessed 3 September 2011

${ }^{48}$ European Commission, 'National Solvit Centres' <http://ec.europa.eu/solvit/site/centres/index_en.htm>accessed 3 September 2011
} 
lodged to a 'home' centre; the centre with the same nationality as the complainer. If the home centre deems the case to be within the remit of the network and apparently involving a breach of EU legislation, the dispute is registered in the network and sent to the 'lead' centre. The 'lead' centre is located in the member state where the problem occurred. Should it accept the case, it subsequently initiates dialogue with the national public authority complained about. ${ }^{49}$ Within the Commission's internal market Directorate General (DG), a Solvit unit is responsible for supporting the network, for example by assisting with the use of the case management database, engaging in dialogue with the centres on cases and organising events bringing all the actors together. The organisation and work process of the network can be illustrated as follows:

Figure 1: The organisation and work process of the Solvit network. Based on Commission illustration (COM 2011b)

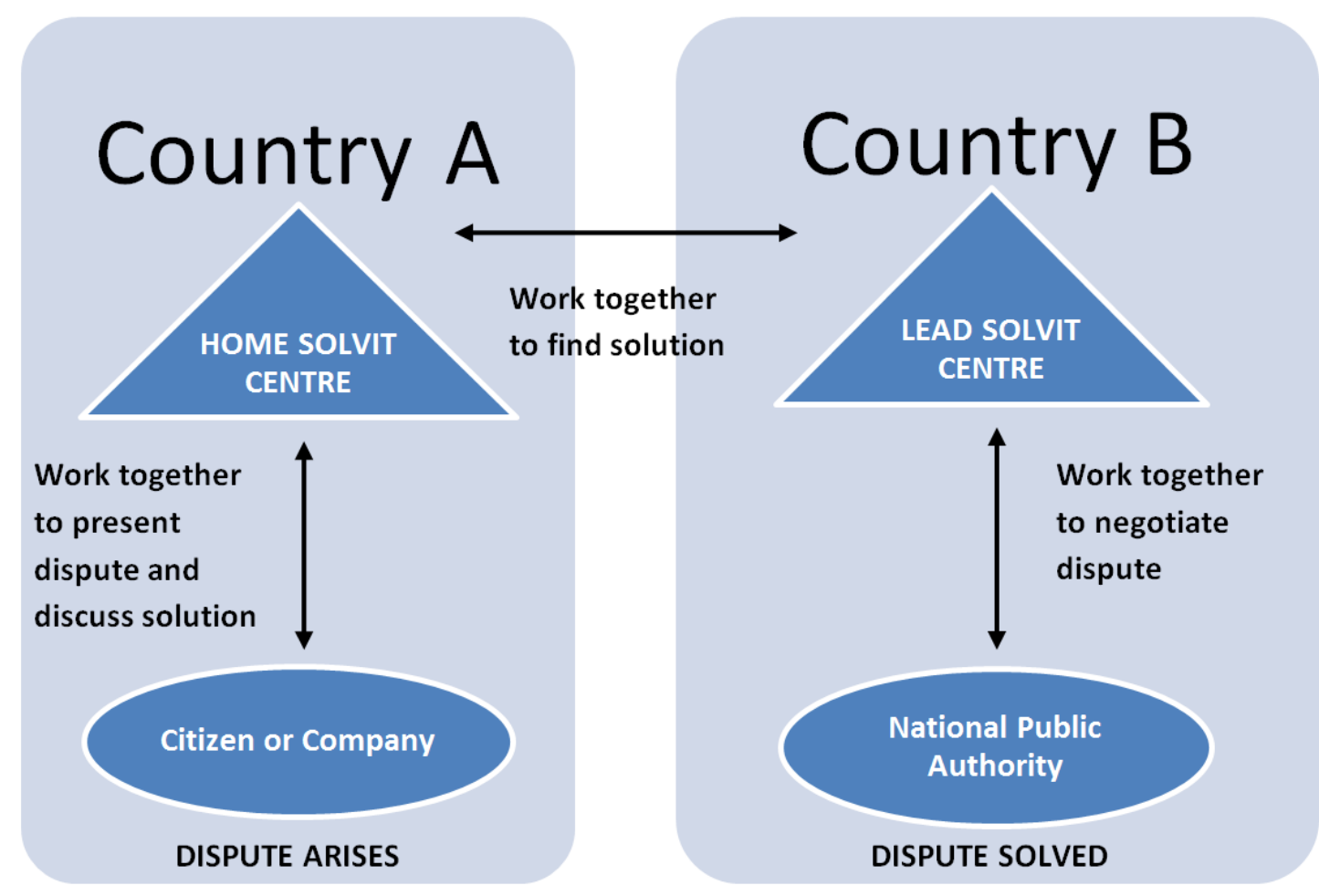

\footnotetext{
${ }^{49}$ COM (2001) 702; European Commission (n 47).
} 
Thus, problem-solving unfolds via several national and cross-national communication and justification processes whereby the application of supranational law is questioned and monitored primarily by national public administrations. The citizen or business needs to present and give reason to the 'home' Solvit centre, which again is to clarify, present and give reason on the disputed matter to the Solvit centre in the other member state: the 'lead' centre. The 'lead' Solvit centre must then present the subject matter and breaches of EU law to the responsible national authority in its own member state. Last, but certainly not least, the responsible national authority must give reason and justify its ways, which again is reviewed and eventually critiqued by the two Solvit centres. As an outcome of the dispute settlement process, the cross-border problem may be solved and misapplication turned into correct application.

Since 2001, Solvit has been institutionalised around a set of main characteristics: Solvit cases have a 'cross-border' element, such as the sale of goods across internal EU borders or the use of social security by European migrant workers. They relate to practical application and not judicial implementation. A matter must concern a situation in which national legislation is deemed in line with the European obligation but the problem arises in the post-transposition phase. ${ }^{50}$ Furthermore, as an alternative to time-consuming and costly legal processes, Solvit aims at speedy redress. A dispute should be solved within a maximum of ten weeks. ${ }^{51}$ Moreover, Solvit constitutes a network of informal problem-solving based on recurring dialogues addressing whether supranational law has been misapplied, questioned and monitored. Problems must be solved without legal proceedings. These characteristics make the Solvit network differ from traditional

\footnotetext{
${ }^{50}$ Most Solvit centres also take on so-called 'Solvit+' cases in which changes to the rules behind national implementation appear necessary (COM 2011d). When a Solvit+ case is dealt with, the problem-solving process will also address the institutional cause of misapplication, that is, incorrect judicial implementation.

${ }^{51}$ COM (2001) 702; European Commission (n 47)
} 
enforcement mechanisms and makes it possible to extend research beyond the conventional focus within compliance studies on timely transposition of EU law.

\subsubsection{Becoming a successful dispute settlement mechanism}

Over the years, Solvit's workload has increased significantly. Figure 2 below illustrates the major increase in the number of cases handled by the Solvit network. The statistics only include cases accepted by the network. Acceptance implies, as mentioned, that a submitted dispute has undergone 'pre-screening', where the home Solvit centre has assessed the case and found it involves a crossborder element, does not involve legislative changes, and agrees with the claimant that it appears likely that EU law has been misapplied. ${ }^{52}$

Figure 2: Total Solvit caseload compared to infringement procedures 2002-2010.

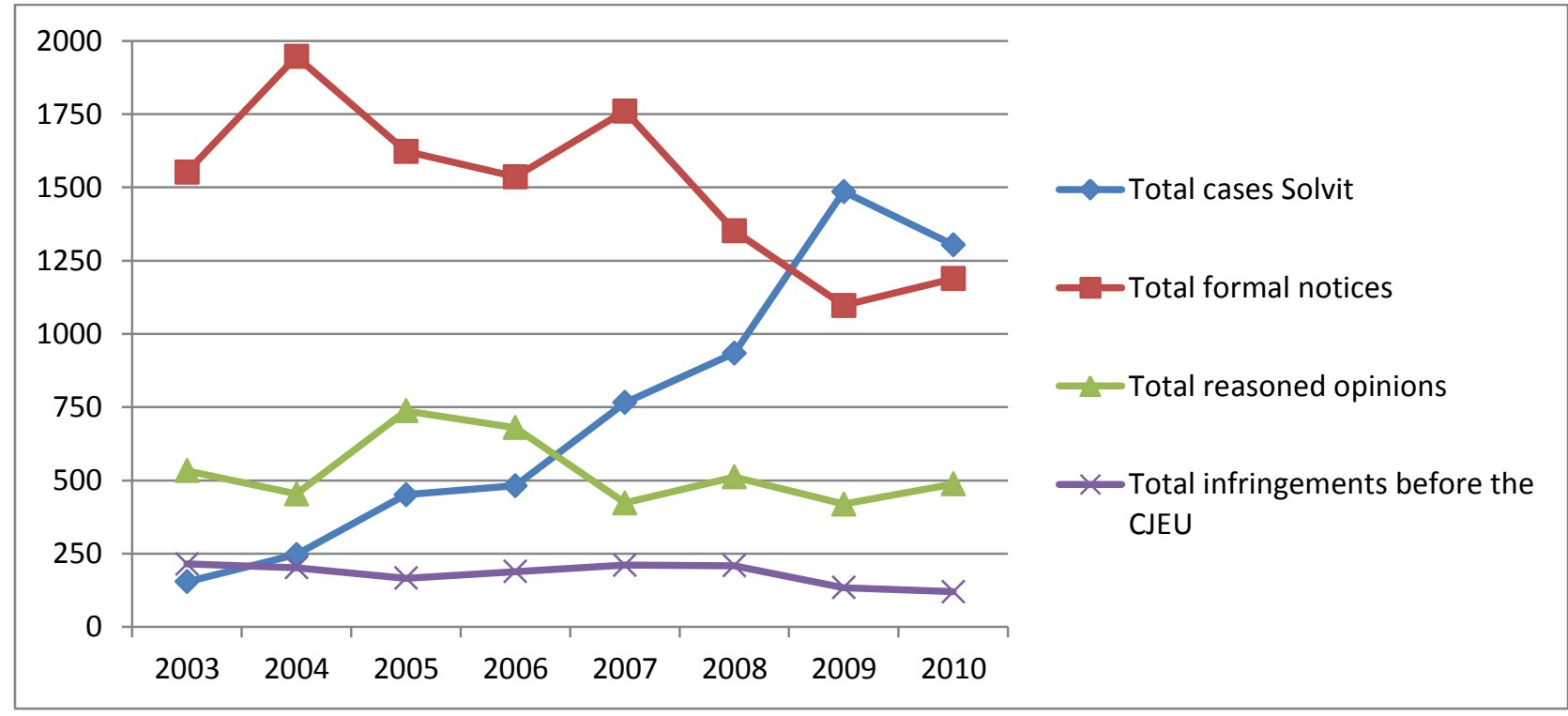

Figure 2: Solvit cases and infringement procedures compared 2002-2010. The data on infringement procedures are from the Commission's Secretariat General's annual reports on monitoring the application of Community law. The data on Solvit cases have been provided by the Commission.

\footnotetext{
${ }^{52}$ European Commission (n 47).
} 
A case accepted by the Solvit regime thus implies that the dispute is regarded as substantial. The network receives a considerable number of other requests which are not accepted as Solvit cases and thus not registered. These include requests concerning purely national problems or require help and guidance on EU only. ${ }^{53}$

In 2003, the network handled 154 cases; by 2010, the figure had grown to 1304 . The request for and success of the informal dispute settlement mechanism stands out when comparing Solvit to the traditional formal EU public enforcement procedures. In comparison as part of the formal legal process of the infringement procedure, in 2010 the Commission sent 1,188 letters of formal notice to the Member States, issued 488 reasoned opinions and referred 120 cases to the CJEU in the same time period. Hence, compared to the much analyzed formal infringement procedure, the Solvit workload is considerable.

\subsection{The effectiveness of transgovernmental networks in dispute settlements and the role of the}

\section{Commission}

From the case-load number itself, it is clear that misapplication cases are brought to Solvit to a considerable extent. Nevertheless, we should still expect - especially from an enforcement perspective - informal dispute resolution to be of limited utility, as national authorities are likely to hinder a dispute mechanism which does not operate by means of 'command and control'. Here we examine effectiveness in accordance with our definition as the resolution speed of the network and the actual ability of the network to resolve cases.

\footnotetext{
${ }^{53}$ European Commission (n 39).
} 
The first proxy for estimating the effectiveness of the network thus concerns the case resolution speed. Is Solvit in practice an expeditious alternative to taking a matter to court? The official aim of the network is to solve cases within ten weeks. Since its establishment, this goal has overall been consistently met. ${ }^{54}$ However, the total time taken to process a claim from its submission is somewhat higher. This is due to the 10 -week deadline only applies from when a case has been accepted by a lead centre. ${ }^{55}$ The home centre's preparation time and the time taken by the lead centre to consider whether to accept the case is therefore not included. In 2010, it took the centres on average five weeks to prepare a case; and one week to consider whether to accept a case from another centre. ${ }^{56}$ The total case processing time is therefore roughly 16 weeks, that is, approximately four months. This is still a short period of time compared with other formal enforcement mechanisms, both public and private, and the network stands out as efficient in terms of prompt dispute resolution.

The second proxy for effectiveness is the ability of the network to resolve cases. Here, the Commission's statistics again provide a picture of a highly successful system. ${ }^{57}$ The official aim of the network is a resolution rate of 80 per cent. This target has generally been achieved from 2002 onwards, although with some differences between the Member States. But what does it mean that a case is resolved? In its 2010 Annual Report, the Commission notes that in practice 'resolved' can, mean two different things: a changed decision or a clarification. ${ }^{58}$ The former entails that the initial administrative act is altered following the intervention of Solvit, namely that misapplication is transformed into correct application. The latter means that the claimant ultimately only receives

\footnotetext{
${ }^{54}$ Ibid.

55 Ibid.

${ }^{56}$ European Commission (n 47).

${ }^{57}$ European Commission (n 39).

${ }^{58}$ European Commission (n 47).
} 
additional information clarifying the background and reasons behind the decision, but the decision is not changed. Both outcomes are important as to how national administrations adapt to EU governance in the sense that they engage national public authorities and claimants in a mode of reasoning structured in EU legal terms. ${ }^{59}$ However, when the dispute is settled by means of a changed decision, this most directly substantiates the effectiveness and impact of the network, as it demonstrates the ability of the network to improve practical application.

The Commission states that 23 per cent of all cases in 2010 ended with a clarification, meaning that the rest of the cases solved led to altered decisions. ${ }^{60}$ This suggests that the network is in fact able to generate alterations to decisions, that is, altering administrative acts. Figure 3 below shows the Solvit centres' estimates of the proportion of their cases which ended in 2010 with a changed decision, as according to our own survey data:

\footnotetext{
${ }^{59}$ Hobolth and Martinsen (n 30).

${ }^{60}$ European Commission (n 47) 20.
} 
Figure 3: The Solvit centre estimation of the proportion of cases in 2010 which ended with a change of the initial decision by the national public authority.

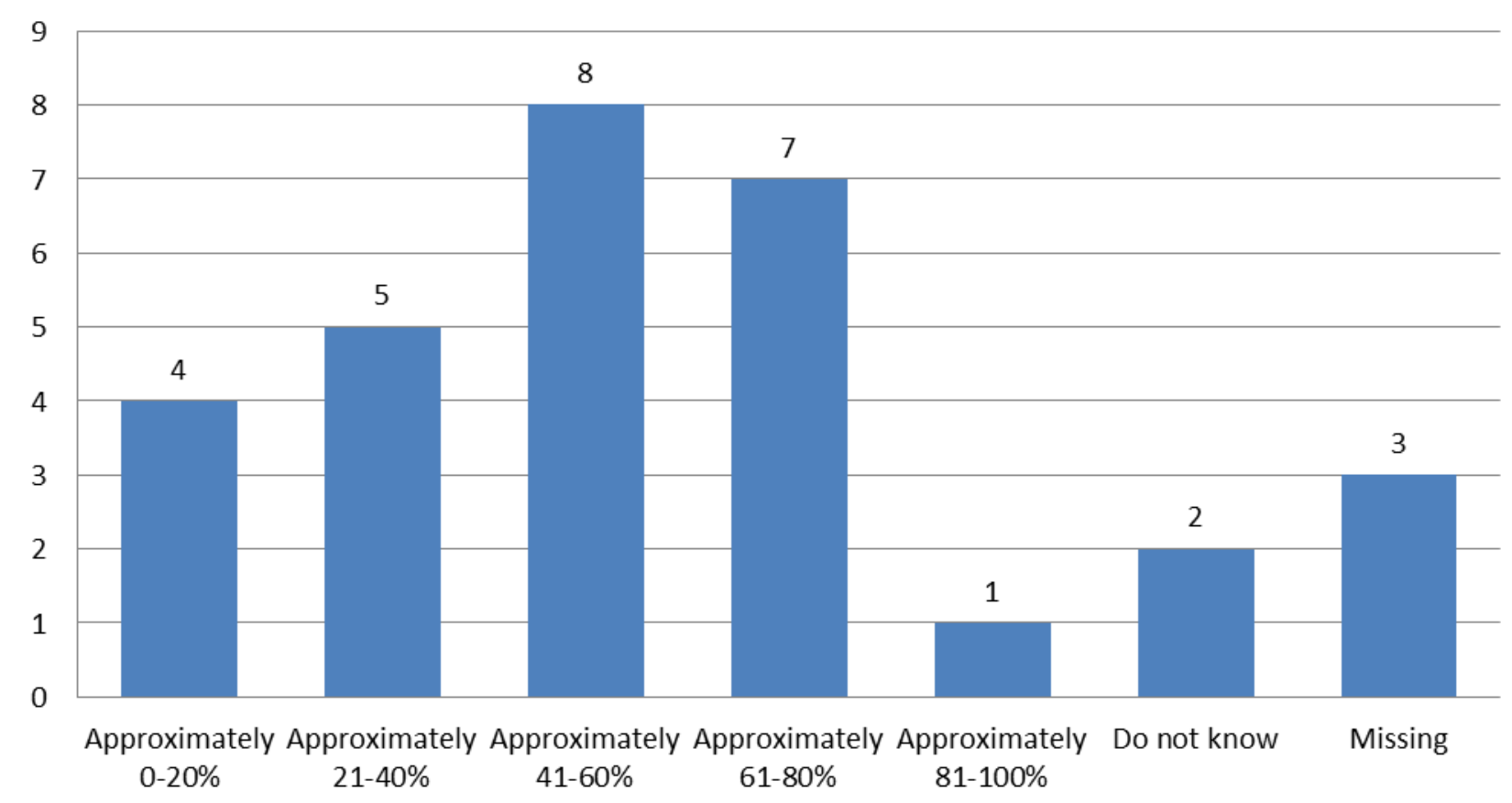

We also asked the centres, as a control, to make a similar assessment of how many cases ended solely with a clarification. The answer to the two questions gave the same picture. Source: Solvit survey 2011, Question 10, 'Of the Solvit cases handled as "lead" in 2010, what was the outcome?"

16 of the Solvit centres report that complaints end with a changed decision in about a half to all cases. Nine indicate that changes are less common. Five centres answered 'do not know' or left the question blank. The figure thus shows that the network is generally able to convince national public authorities to alter their practices.

Figure 4 points out what the centre reports to be the preconditions for resolving cases: 


\section{Figure 4: The Solvit centres estimation of the preconditions for resolving cases.}

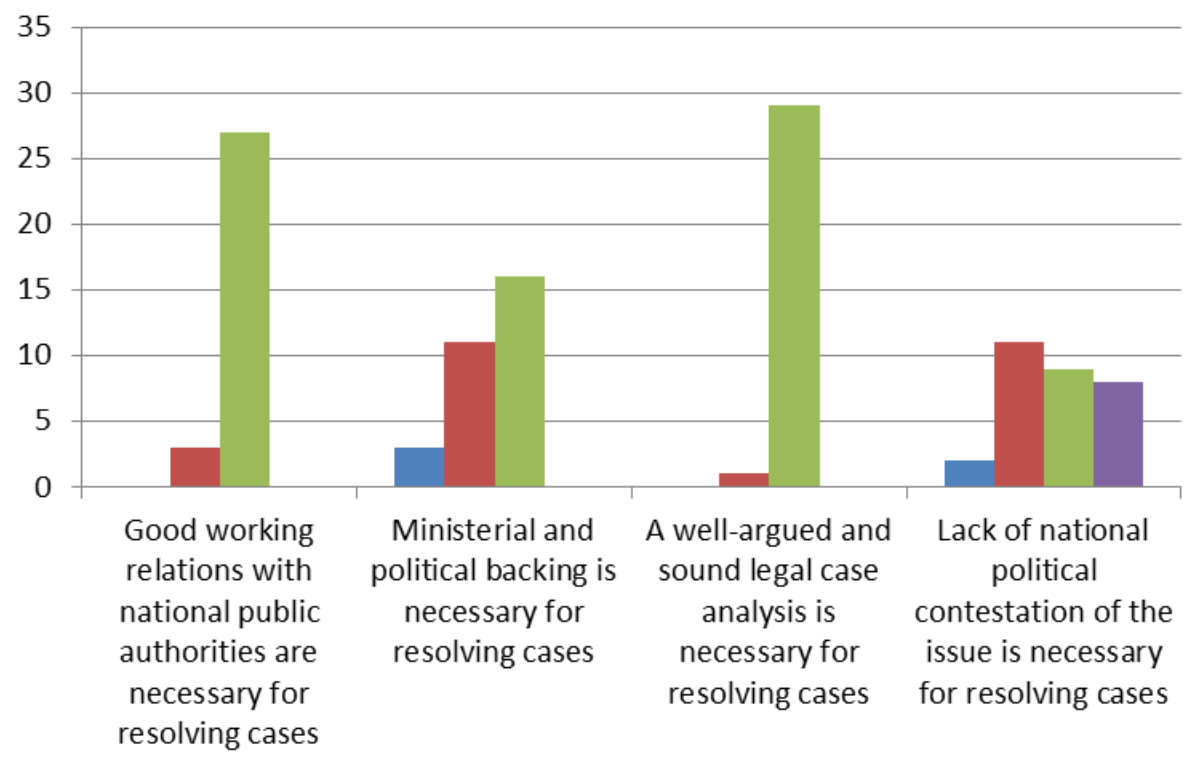

- Strongly disagree / disagree

neither agree nor disagree

Agree / strongly agree

Do not know and missing

The categories strongly disagree/agree and agree/strongly disagree have been combined. 'Do not know' and missing answers have also been joined together. Source: Solvit survey 2011, Question 20, 'To what extent, if at all, do you agree with the following statements concerning the preconditions for resolving cases?'

We asked the centres to assess the importance of four aspects: good working relations with other public authorities, ministerial support, legal case analysis and political contestation. No ranking was requested. The responses substantiate that all factors have some importance - but not equally so. There is a clear trend in what aspects the centres 'agree' or 'strongly agree' with as important. Good working relations with other parts of the national administration together with sound legal case analysis stand out as very important. Several centres also stress the necessity of ministerial and political backing. This element was particularly emphasised by one centre in a supplementary comment:

...unfortunately we do not feel support for SOLVIT cases from our superiors, especially for citizen cases[.] This is due to the fact that SOLVIT [...] is established at the Ministry of Industry and Trade so the attention from our hierarchy concentrates a lot on business cases but 
cases of ordinary citizens are not viewed that importantly. For example, social security cases which affect daily life and situations of European families [...] [are] not seen as something significant and we are almost discouraged to talk about them/advertise them, etc. ${ }^{61}$

The survey data thus highlight the importance of good working relations, legal analysis and to a large extent also ministerial backing. On the other hand, overall, the centres do not find the extent to which an issue is politicised of high importance.

All in all, the official data presented by the Commission suggests that the network is an efficient problem-solving mechanism. Resolution speed is high compared to, for example, legal proceedings or formal infringement proceedings instigated by the Commission. Efficiency is also supported by the survey data collected for this analysis. Decentralised informal problem solving is, in fact, able to address gaps between the transposition and practical application of EU legislation. We do see some differences in outcomes in that the end result may amount to a change in a decision or solely a clarification. However, the vast majority of Solvit cases lead to a change in the original decisions and even in clarification cases, the work of the network promotes and strengthens the use of arguments framed in EU legal terms within national public authorities to justify the action they have taken.

\footnotetext{
${ }^{61}$ Source: Solvit Survey 'Academic survey of the Solvit network' (2011) Own web-survey submitted to and replied by all National Solvit Centres, Question 28, 'If you have any further comments regarding the topics covered in the survey please enter them here')
} 


\subsubsection{The role of the Commission in informal dispute settlements}

Our survey data provides new insights into the role of the Commission. The survey points out that most national Solvit centres have contact with the EU Solvit unit, i.e. the Commission, on a regular basis. Some on an almost daily basis, others weekly, and others only a few times over the course of a month. In general, the European Commission is closely involved and consulted when the application of internal market rules is scrutinized:

Twelve centres are in contact with the Commission weekly or more; 18 a few times over the course of a month or year. The level of contact is thus high although varying, substantiating the central role of the Commission in the network. The involvement of the Commission proves essential for different purposes. When asked about the purposes of the contact, three different ways of assisting the centres stand out as central:

Figure 5: The purpose of the contact with the Commission.

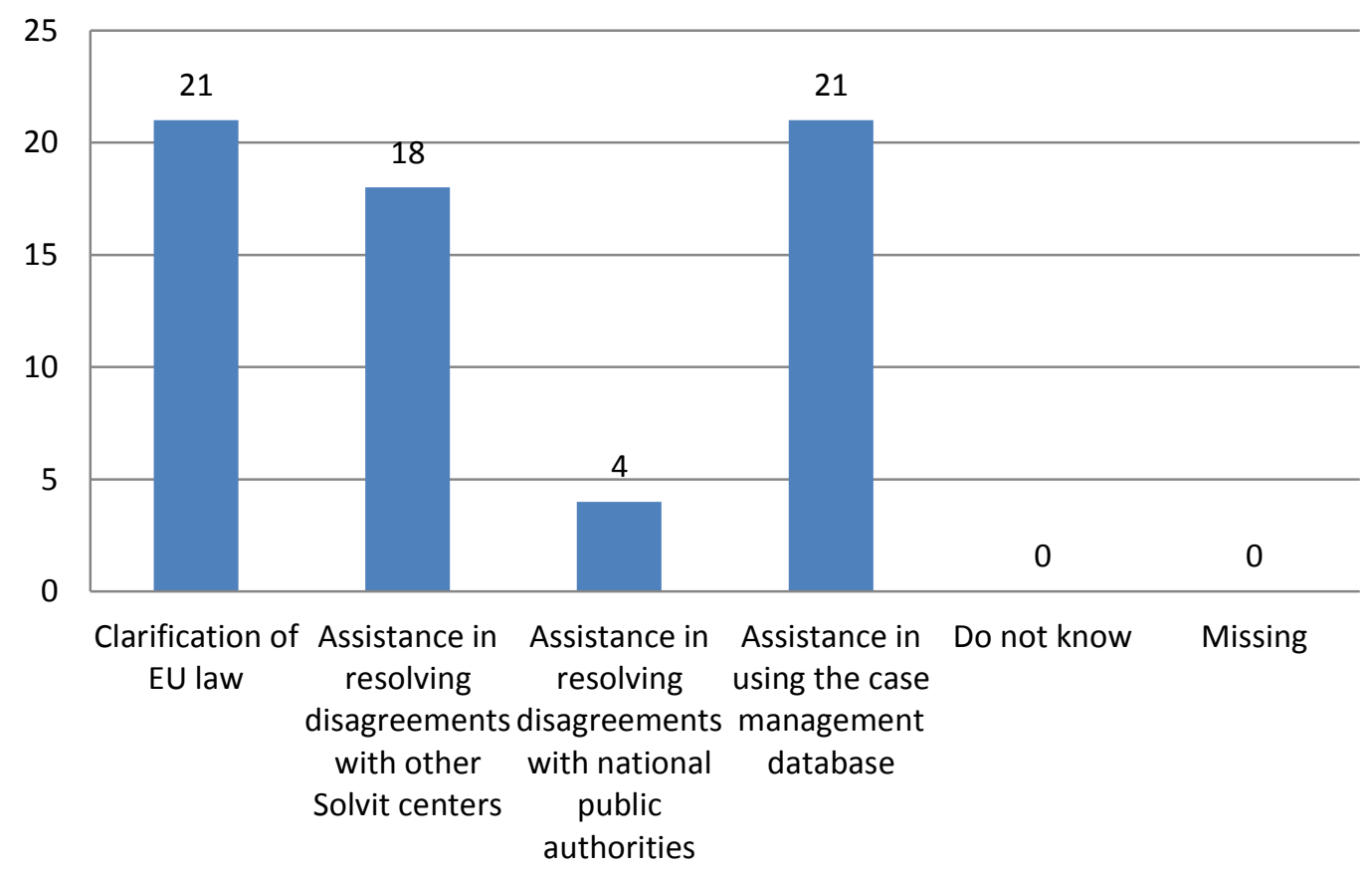

The respondents were invited to tick as many of the stated reasons as relevant. Source: Solvit survey 2011 , Question 5, 'What is the purpose of the contact with the European Commission?' 
The Commission assists the centres regarding the daily practices of the network. This includes giving advice on how to use the case management database, with understanding the legal content and meaning of EU law, as well as assisting with the solution of horizontal disagreements with other Solvit centres. However, the Commission does not appear to intervene very much when there are disagreements between Solvit centres and national public authorities within Member States. Thus, the Commission plays a role in the more technical matters of the network,. and assumes a supervisory role in the network being continuously involved in the dispute settlements.

Moreover, for most Solvit centres, contact with the Commission has increased over the years, as the responses to the question below demonstrate:

\section{Figure 6: Changes in the level of contact with the Commission.}

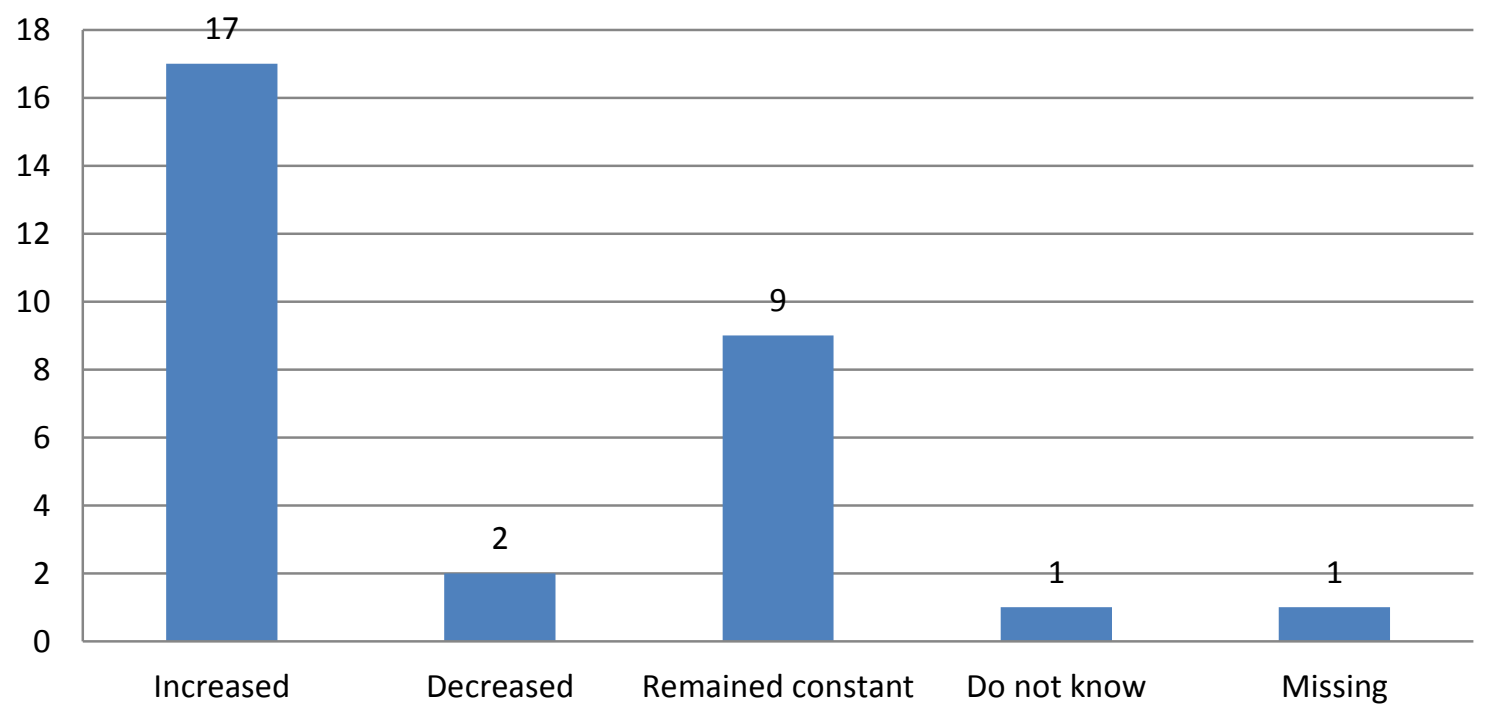

Source: Solvit survey 2011, Question 7, 'Since your Solvit centre was established, the amount of contact with the European Commission has in general...?'

Nevertheless, the continuous and increasing involvement of the Commission in the dispute settlement of the network does not tell us whether the Commission enjoys sufficient authority to have its opinions and interpretations taken into account when there is a conflict between the view of 
the Commission and that of the national authority. In the survey we inquired into the degree to which the Commission's view supersedes national views in the event of a conflict between the two. The result was unequivocal. Where a conflict arises, the supranational hierarchy is clear. If the preferred case solution of the national public authority is in conflict with the recommendations made by the Commission, the Commission's recommendations are followed:

\section{Figure 7: The Commission's authority in the network.}

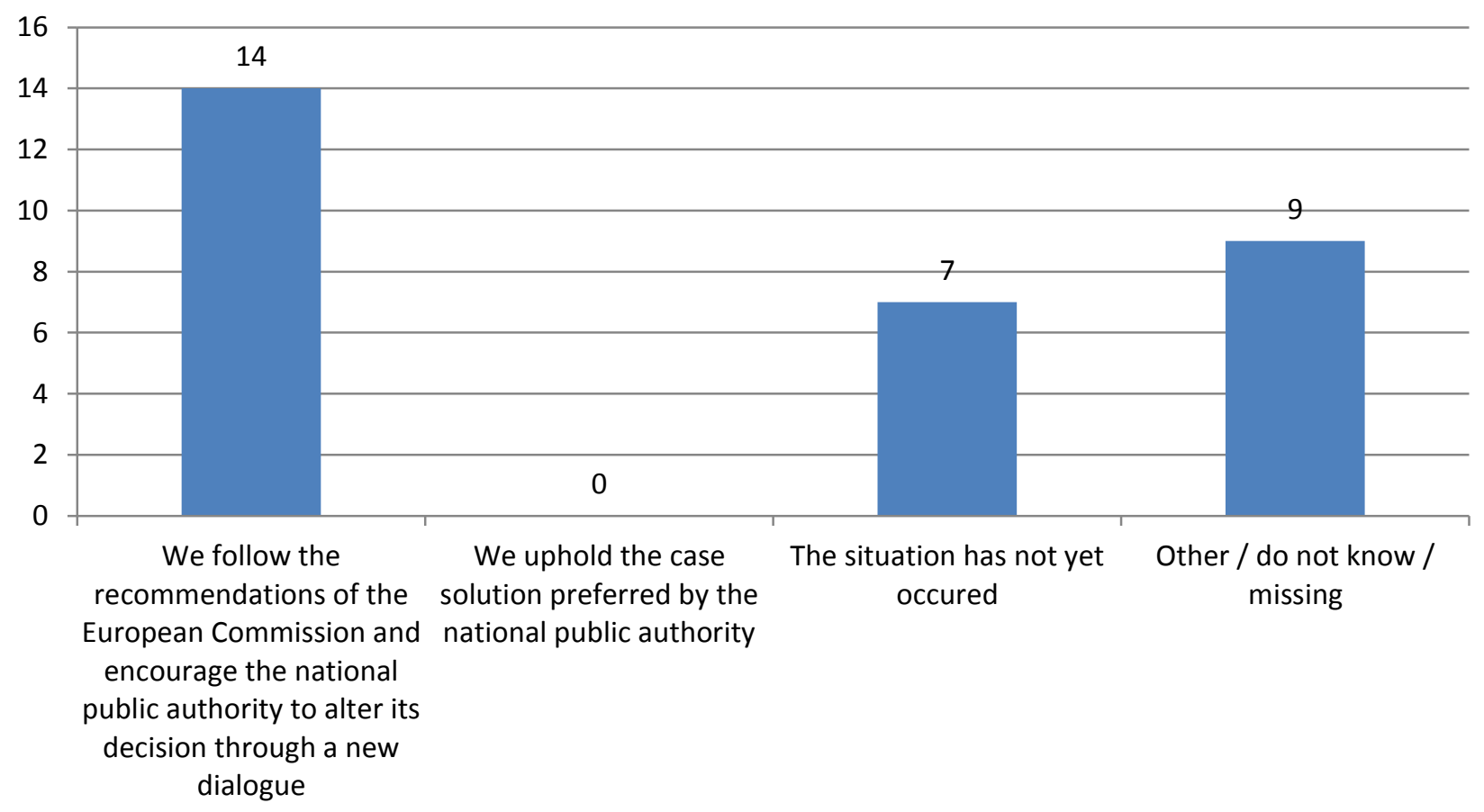

Source: Solvit Survey 2011, Question 17, 'If the European Commission recommends a case solution different from the one preferred by your national public authority, what do you do?'

Thus, the Commission plays a central role in assisting and advising on dispute settlements.

Although the process of resolution appears horizontally organized between three entities, namely the individual or firm with a complaint, the relevant Solvit centres and the national public authority against which a complaint has been made, the Commission (vertically) shadows the dispute and masters the database, assists on the clarification of EU law, and has a final say when conflicts 
appear between national units. Although this form of alternative dispute settlement is not as coercive as traditional enforcement procedures, it operates in the shadow of supranational hierarchy. ${ }^{62}$ If a conflict is unsolved or the solution does not appear to follow EU law, the Commission may decide to open an infringement procedure as the next step. ${ }^{63}$ Against this background, informal dispute settlement stands out as an attractive alternative. This may in part explain the success of the transgovernmental network as a dispute settlement mechanism. Although horizontal in structure, it has a vertical element of supranational supervision.

\section{Conclusion}

Our findings demonstrate that misapplication of EU law continues to occur on a regular basis even after the transposition of EU rules into national legislation. Despite considerable research being undertaken on the transposition of EU law, this does not necessarily tell us much about compliance in practice. Citizens and enterprises encounter daily barriers to exercising their rights and complying with the obligations formally provided by internal market law. Correct practical application depends on the extent to which national public authorities at different governance levels understand and are willing to act in accordance with EU legislation, and not simply on transposition of the EU rules into national law.

The findings of this empirical qualitative study demonstrate that the EU's enforcement-management system has added an important de-centralized management dimension by means of transgovernmental networks. The findings thus point to transgovernmental networks such as Solvit as important and effective structure to address misapplication of EU law. The chapter has

\footnotetext{
${ }^{62}$ T.A. Börzel 'European governance: Negotiation and competition in the shadow of hierarchy' (2010) 48(2) Journal of Common Market Studies 191.

${ }^{63}$ See also European Commission, 'Commission Staff working document setting out the approach for assessing the conformity of solutions proposed by the SOLVIT network with Community law' SEC (2004) 1159.
} 
thus contributed to fill in the black hole of developing a better understanding of EU law in action. Transgovernmental networks are effectively located in the core executives of the Member States, but reporting back to and taking advice from the Commission. ${ }^{64}$ The Commission has quietly and discreetly rearmed in its battle against misapplication of EU law relating to the functioning of the internal market by Member States by focusing on compliance problems in the post-transposition stage. Alternative dispute settlement networks have developed and proven considerably effective as a mechanism of de-centralized management practices ensuring EU compliance. The informal dispute resolution provided by a TGN such as Solvit provides a strong, supplementary means of enforcing EU law along with the two traditional public and private enforcement mechanisms . Whilst national courts are de-centralized private enforcement mechanisms, ${ }^{65}$ a transgovernmental network constitutes a de-centralized management mechanism which may be remarkably effective and successful in solving problems of misapplication.

In part, this success is explained by the fact that national public authorities become supervisors of national compliance while operating close to the units under 'surveillance'. The national Solvit centres are part of the national executives, located and financed there. At the same time, however, they are responsible for overseeing the conduct of their national counterparts; to question it, evaluate it, report on it and - eventually - take steps to ensure that it is in accordance with EU legislation. In this way, they become entrusted supervisors of EU laws and key institutions in managing practical application, but in contrast to the national courts, do so in a manner more informed by trust, less by the threat of sanctions. They thus constitute an important part of the 'European executive space', monitoring EU law but located in the national administrations. ${ }^{66}$

\footnotetext{
${ }^{64}$ On effectiveness and the importance of learning, see also Hobolth and Martinsen (n 30).

${ }^{65}$ Slepcevic (n 14).

${ }^{66}$ J. Trondal 'An Emergent European Executive Order' (Oxford University Press 2010).
} 
Although horizontal in structure and operating by means of management, the transgovernmental Solvit network has an important vertical dimension. The Commission occupies a central role in assisting and advising dispute settlements. The Commission's involvement implies that, should the softer means of management not work, enforcement proceedings may be initiated. The continuous presence of the Commission means that supranational hierarchy shadows dispute resolution. In the shadow of supranational hierarchy, informal dispute settlements stand out as the attractive alternative. By creating a transgovernmental network of de-centralised supervision through national public authorities, the Commission has taken another important step in boosting the enforcementmanagement machinery of the $\mathrm{EU}^{67}$, capable of detecting and resolving some of the disputes over the practical application of EU rule 'below the tip of the non-compliance iceberg, ${ }^{68}$

\footnotetext{
${ }^{67}$ Tallberg (n 13).

${ }^{68}$ Börzel (n 62).
} 


\section{References}

Alter, K (2001). Establishing the supremacy of European Law: The making of an international rule of law in Europe. Oxford: Oxford University Press.

Alter, K.J. and Vargas, J. (2000) 'Explaining Variation in the Use of European Litigation Strategies. European Community Law and British Gender Equality Policy', in: Comparative Political Studies, pp. $452-82$.

Börzel, T.A. (2001). Non-compliance in the European Union: Pathology or statistical artefact? Journal of European Public Policy 8(5): 803-824.

Börzel, T.A. (2010). European governance: Negotiation and competition in the shadow of hierarchy. Journal of Common Market Studies 48(2): 191-219.

Börzel, T.A., Hofmann, T., Panke, D. \& Sprungk, C. (2010). Obstinate and inefficient: Why Member States do not comply with European law. Comparative Political Studies 43(11): 13631390.

Bursens, P. (2002). Why Denmark and Belgium have different implementation records: On transposition laggards and leaders in the EU. Scandinavian Political Studies 25(2): 173-195.

CASOS, Center for Computational Analysis of Social and Organizational Systems (2010). ORA. Pittsburgh: Carnegie Mellon University. Found 21 August 2010: http://www.casos.cs.cmu.edu/projects/ora 
Chayes, A. \& Chayes, A.H. (1993). On compliance. International Organization 47(2): 175-205.

COM, European Commission (2001a). Communication from the Commission to the Council, the European Parliament, the Economic and Social Committee and the Committee of the Regions Effective problem solving in the Internal Market ("SOLVIT"). 2001/702. Published 27 November, Found 3 September 2011: http://eur-

lex.europa.eu/LexUriServ/LexUriServ.do?uri=CELEX:52001DC0702:EN:NOT

COM, European Commission (2001b). Commission recommendation of 7 December 2001 on principles for using "SOLVIT" -- the Internal Market Problem Solving Network (Text with EEA relevance) (notified under document number C(2001) 3901). Published 7 December, Found 3 September 2011: $\underline{\text { http://eur- }}$ lex.europa.eu/LexUriServ/LexUriServ.do?uri=CELEX:32001H0893:EN:NOT

COM, European Commission (2004). Commission Staff working document setting out the approach for assessing the conformity of solutions proposed by the SOLVIT network with Community law. Published 17 September, Found 3 September 2011:

http://register.consilium.europa.eu/pdf/en/04/st12/st12600.en04.pdf

COM, European Commission (2007a). 24 ${ }^{\text {th }}$ Annual Report on Monitoring the Application of EU Law: Annex. Published 17 July, Found 3 September 2011:

http://ec.europa.eu/eu_law/infringements/pdf/sec_2007_0976_1_en.pdf 
COM, European Commission (2007b). A Europe of results - Applying Community law. Published 5 September, Found 10 October 2011:

http://ec.europa.eu/eu_law/docs/docs_infringements/com_2010_70_en.pdf

COM, European Commission (2010). $27^{\text {th }}$ Annual report on monitoring the application of EU Law:

Statistical annex. Published 1 October, Found 3 September 2011:

http://ec.europa.eu/eu_law/docs/docs_infringements/annual_report_27/statannex_1-3_en.pdf

COM, European Commission (2011a). SOLVIT 2010 report: Development and performance of the SOLVIT network. Found 3 September 2011:

http://ec.europa.eu/solvit/site/docs/solvit_2010_report_en.pdf

COM, European Commission (2011b). About SOLVIT. Found 3 September 2011:

http://ec.europa.eu/solvit/site/about/index_en.htm

COM, European Commission (2011c). National Solvit Centres. Found 3 September 2011:

http://ec.europa.eu/solvit/site/centres/index_en.htm

COM, European Commission (2011d). Background: Annual reports. Found 3 September 2011: http://ec.europa.eu/solvit/site/background/index_en.htm

COM, European Commission (2011e). $28^{\text {th }}$ Annual report on monitoring the application of EU Law. Published 29 September, Found 24 January 2012:

http://ec.europa.eu/eu_law/infringements/infringements_annual_report_28_en.htm 
Conant, L.J. (2002). Justice contained: Law and politics in the European Union. Ithaca, NY: Cornell University Press.

Council, Council of the European Union (2002). Internal market problem-solving - Council conclusions on the "SOLVIT" network. 6503/02 (Presse 41 - G). Found 3 September 2011: http://ec.europa.eu/solvit/site/docs/conclusions_en.pdf

Couper, M.P. (2000). Web surveys: A review of issues and approaches. Public Opinion Quarterly 64: 464-494.

Couper, M.P., Traugott, M.W. \& Lamias, M.J. (2001). Web survey design and administration. Public Opinion Quarterly 65: 230-253.

De Vaus, D.A. (2001). Surveys in social research (5 ${ }^{\text {th }}$ ed.). London: Routledge.

Duina, F.G. (1999). Harmonizing Europe: nation-states within the Common Market. Albany, NY: State University of New York Press.

Eberlein, B. and Newman, A., L. (2008) 'Escaping the Intergovernmental Governance Dilemma? Incorporated Transgovrnmental Networks in the European Union', in: Governance, pp. 25-52. Egeberg, M. (2008). European government(s): Executive politics in transition? West European Politics 31(1-2): 235-257. 
Falkner, G. (2013). The JCMS Annual Review Lecture. Is the European Union Losing Its Credibility?' Journal of Common Market Studies 51: 13-30

Falkner, G. \& Hartlapp, M. (2009). Problems of operationalization and data in EU compliance research. European Union Politics 10(2): 281-304.

Falkner, G., Hartlapp, M. \& Treib, O. (2007) Worlds of compliance: Why leading approaches to European Union implementation are only 'sometimes-true theories'. European Journal of Political Research 46(3): 395-416.

Falkner, G., Hartlapp, M., Leiber, S. \& Treib, O. (2004). Non-compliance with EU directives in the Member States: Opposition through the backdoor. West European Politics 27(3): 452-473.

Fricker, R.D. \& Schonlau, M. (2002). Advantages and disadvantages of Internet research surveys: Evidence from the literature. Field Methods 14(4): 347-367.

Golub, J. (1996a) 'Modelling Judicial Dialogue in the European Community: The Quantitative Basis of preliminary References to the ECJ', EUI Working Paper RSC, No. 96/58: 1-30.

Golub, J. (1996b) 'The Politics of Judicial Discretion: Rethinking the Interaction between National Courts and the European Court of Justice', West European Politics, 19(2): 360-85.

Groves, R.M. (2009). Survey methodology (2 ${ }^{\text {nd }}$ ed.). Oxford: Wiley-Blackwell. 
Hartlapp, M. (2007). On enforcement, management and persuasion: Different logics of implementation policy in the EU and the ILO. Journal of Common Market Studies 45(3): 653-674.

Haverland, M. \& Romeijn, M. (2007). Do Member States make European policies work? Analysing the EU transposition deficit. Public Administration 85(3): 757-778.

Haverland, M., Steuenberg, B. \& van Waarden, F. (2011). Sectors at different speeds: Analysing transpostion deficits in the European Union. Journal of Common Market Studies 49(2): 265-291.

Hobolth, M. and Martinsen, D.S. (2013) 'Transgovernmental Networks in the European Union: Improving Compliance Effectively?', in: Journal of European Public Policy, pp. 1406-24.

Kaeding, M. and Voskamp, F. (2011) 'Better implementation of EU legislation is not just a question of taking Member States to Court', in: EIPA Working Paper, pp. 1-16.

Koops, C.E. (2011) 'EU Compliance Mechanisms: The Interaction between the Infringement Procedures, IMS, SOLVIT and EU-Pilot', in: Amsterdam Law School Research Paper, pp. 1-39.

König, T. and Luetgert, B. (2009) 'Troubles with Transposition? Explaining Trends in MemberState Notification and the Delayed Transposition of EU Directives', in: British Journal of Political Studies, pp. 163-94.

Maestenbroek, E. (2003). Surviving the deadline: The transposition of EU directives in the Netherlands. European Union Politics 4(4): 371-395. 
Mastenbroek, E. (2005). EU compliance: Still a 'black hole’? Journal of European Public Policy 12(6): 1103-1120.

Martinsen, D.S., Wind, M. \& Rotger, G.P. (2009). The uneven legal push for Europe: Questioning variation when national courts go to Europe. European Union Politics 10(1): 63-88.

Schneider, A.K. (2006). Not quite a world without trials: Why international dispute resolution is increasingly judicialized. Journal of Dispute Resolution 119: 119-129.

Slaughter, Anne-Marie. 2004. A New World Order. Princeton: Princeton University Press

Slaughter, Anne-Marie and Hale, Thomas N. 2010. "Transgovernmental networks and multi-level governance”. In: Henrik Enderlein, Sonja Wälti and Michael Zürn (eds.), Handbook on Multi-level Governance, Cheltenham \& Northampton: Edward Elgar, pp. 358-369

Slepcevic, R. (2009). The judicial enforcement of EU law through national courts: possibilities and limits. Journal of European Public Policy 16(3): 378-394.

Solvit Survey. (2011). Academic survey of the Solvit network. Own web-survey submitted to and replied by all National Solvit Centres.

Steuenberg, B. \& Toshkov, D. (2009). Comparing transposition in the 27 Member States of the EU: the impact of discretion and legal fit. Journal of European Public Policy 16(7): 951-970. 
Stone Sweet, A. \& Brunell, T.L. (1998). Constructing a supranational constitution: Dispute resolution and governance in the European Community. American Political Science Review 92(1): $63-81$.

Sverdrup, U. (2004). Compliance and conflict management in the European Union: Nordic exceptionalism. Scandinavian Political Studies 27(1): 23-43.

Sverdrup, U. (2005). Implementation and European integration: A review essay. ARENA Working Paper No. 25. October 2005. Found 8 September 2011:

http://www.sv.uio.no/arena/english/research/publications/arenapublications/workingpapers/working-papers2005/wp05_25.pdf

Tallberg, J. (2002). Paths to compliance: Enforcement, management and the European Union. International Organization 56(3): 609-643.

Tallberg, J. (2003). European governance and supranational institutions: Making states comply, London, New York: Routledge.

Thurner, P. W. and Binder, M. (2009). "European Union transgovernmental networks: The emergence of a new political space beyond the nation-state?". European Journal of Political Research 48(1): 80-106 
Treib, O. (2008). Implementing and complying with EU governance outputs. Living Reviews in European Governance 3(5).

Trondal, Jarle. 2010. An Emergent European Executive Order. Oxford, Oxford University Press.

Versluis, E. (2007). Even rules, uneven practices: Opening the 'black box' of EU law in action. West European Politics 30(1): 50-67.

Wind, M., Martinsen, D.S., and Rotger, G.P. (2009) 'The Uneven Legal Push for Europe.

Questioning Variation when National Courts go to Europe', in: European Union Politics, pp. 63-88. 